\title{
Cholesterol depletion induces transcriptional changes during skeletal muscle differentiation
}

\author{
Ana CB Possidonio ${ }^{1}$, Milene Mirandaㄹ, Gustavo B Gregoracci ${ }^{3}$, Fabiano L Thompson ${ }^{4}$, Manoel L Costa ${ }^{1}$ \\ and Claudia Mermelstein ${ }^{1 *}$
}

\begin{abstract}
Background: Myoblasts undergo major changes in their plasma membrane during the initial steps of skeletal muscle differentiation, including major alterations in the distribution of cholesterol. Cholesterol is involved in crucial membrane functions, such as fluidity, and permeability, and in the organization of specialized membrane microdomains (or lipid rafts). We have previously shown that alterations in cholesterol levels in myoblasts induce changes in proliferation and differentiation, which involves activation of Wnt/beta-catenin signaling pathway. In this study we used methyl- $\beta$-cyclodextrin (MbCD) to extract cholesterol from the membrane of chick skeletal muscle cells grown in culture. Using lon Torrent-based sequencing, we compared the transcriptome of untreated and MbCD treated cells. Our aim was to define the genes that are expressed in these two conditions and relate their expression to cellular functions.
\end{abstract}

Results: Over 5.7 million sequences were obtained, representing $671.38 \mathrm{Mb}$ of information. mRNA transcriptome profiling of myogenic cells after cholesterol depletion revealed alterations in transcripts involved in the regulation of apoptosis, focal adhesion, phagosome, tight junction, cell cycle, lysosome, adherens junctions, gap junctions, p53 signaling pathway, endocytosis, autophagy and actin cytoskeleton. Lim domain only protein 7 mRNA was found to be the highest up-regulated feature after cholesterol depletion.

Conclusions: This is the first study on the effects of membrane cholesterol depletion in mRNA expression in myogenic cells. Our data shows that alterations in the availability of plasma membrane cholesterol lead to transcriptional changes in myogenic cells. The knowledge of the genes involved in the cellular response to cholesterol depletion could contribute to our understanding of skeletal muscle differentiation.

\section{Background}

During skeletal muscle development, myoblasts undergo a series of cell divisions before they became post mitotic. A number of biochemical and morphological changes occurs in post mitotic myoblasts before their fusion into multinucleated myotubes. These changes include myoblast elongation to a bipolar shape, membrane recognition and alignment, culminating in myoblast fusion. Changes in the composition and structure of the plasma membrane accompany all muscle differentiation steps. One key molecule that regulates the structure and function of the sarcolemma is cholesterol. It has been shown that the addition of cholesterol to the cultured medium

\footnotetext{
* Correspondence: mermelstein@ufrj.br

${ }^{1}$ Instituto de Ciências Biomédicas, Universidade Federal do Rio de Janeiro, Rio de Janeiro, Brazil

Full list of author information is available at the end of the article
}

before fusion onset inhibits fusion, and that a decrease in membrane cholesterol is necessary for myoblast fusion [1-3]. Using filipin and freeze-fracture electron microscopy, Sekiya and collaborator [4] showed that the early stages of myoblast fusion were characterized by the depletion of cholesterol from the membrane apposition sites, at which the plasma membranes of two adjacent cells were in close contact. Since cholesterol plays an essential role controlling both plasma membrane fluidity and the organization of specialized micro-domains (lipid rafts), it is important to understand its role during myogenesis. One simple approach to study the role of cholesterol during muscle differentiation is to selectively deplete membrane cholesterol from in vitro grown myogenic cells. A widely used way of depleting the cholesterol content of cell membranes in a variety of cell types is the incubation of cells with methyl- $\beta$-cyclodextrin $(\mathrm{MbCD})$, a 
compound that has a hydrophobic cavity with a high affinity for cholesterol $[5,6]$. Our group has shown that cholesterol depletion by $\mathrm{MbCD}$ enhances the fusion of chick-cultured myoblasts and induces the formation of multinucleated myotubes that are more than 3 times thicker than untreated cultures [7]. We also showed that $\mathrm{MbCD}$ induces the activation of the Wnt/ $\beta$-catenin signaling pathway and increases the proliferation of myoblasts [8-10]. However, it is not yet known the genes that are involved in the cellular events that occur after cholesterol depletion of muscle cells. Here, we investigated the effects of membrane cholesterol depletion in the whole transcriptomic profile of chick skeletal muscle cells, using an Ion Torrent-based sequencing. In addition, the morphology of the cholesterol-depleted cells was also evaluated by means of immunofluorescence microscopy.

\section{Results}

Differences in transcription between untreated and MbCD-treated myogenic cells

To better understand the molecular and cellular basis involved in MbCD-induced muscle differentiation, we analyzed the transcriptome of chick cultured muscle cells after cholesterol depletion. Over 8.5 million sequences were obtained, from which over 5.7 million passed quality control, representing 671.38 mega basepairs of information (Additional file 1: Table S1).

From a total of 4,415 identified transcripts, 1,408 (31.89\%) had their transcription significantly modified. Among these, 785 genes were overexpressed in the MbCD-treated myogenic cells compared to the control, indicating up-regulation (Table 1). On the other hand, 623 genes had reduced expression in the MbCD-treated myogenic cells compared to the control, indicating downregulation (Table 1). The cellular processes that were affected (either down- or up-regulated) after cholesterol depletion were cell growth and death, cell communication, transport and catabolism, and cell motility (Tables 2 and 3).

The group of genes with the highest down-regulation levels after MbCD treatment is involved in apoptosis, focal adhesion, phagosome, tight junction, cell cycle, lysosome, adherens junctions and gap junctions (Table 2). Interleukin-1 receptor-associated kinase 2 mRNA was found to be the highest down-regulated feature (Table 2).

Genes coding for proteins related to adherens junctions, apoptosis, lysosome, p53 signaling pathway, cell cycle, focal adhesion, endocytosis, regulation of autophagy and regulation of actin cytoskeleton were up-regulated after MbCD treatment (Table 3). Lim domain only protein 7 (LMO7) mRNA was found to be the highest upregulated feature (Table 3). Another highly up-regulated mRNA after cholesterol depletion was the lysosomalassociated membrane protein 1/2 (LAMP 1/2).

\section{Morphological analysis of cholesterol-depleted myogenic cells}

In order to correlate the transcriptomic analysis with structural characteristics, we analyzed the effects of cholesterol depletion in the morphology of myogenic cultured cells. The effects of MbCD in chick myogenic cultures can be clearly visualized after an immunofluorescence labeling using an antibody against the sarcomeric protein alphaactinin and the nuclear dye DAPI (Figure 1). Myofibrils labeled with alpha-actinin can be seen in untreated and MbCD-treated cells, but it is noticeable that MbCD treated-cultures displayed a higher number of myofibrils than control cultures (Figure 1). Quantification of the number of myofibrils present within myotubes showed that MbCD treatment induces a $80 \%$ increase in the number of myofibrils. The presence of well defined striated myofibrils is an indicator of myogenic differentiation. The presence of much thicker myotubes and a higher number

Table 1 Transcriptomic metadata of chick myogenic cells

\begin{tabular}{|c|c|c|c|}
\hline & Transcriptome control & MbCD-treated transcriptome & \\
\hline MG-RASTID & 4512803.3 & 4512804.3 & \\
\hline Transcriptome Size (post QC) (Mbp) & 337.68 & 333.70 & \\
\hline Average size (post QC) (bp) & $115 \pm 62$ & $117 \pm 58$ & \\
\hline Total number of sequences (post QC) & $2,926,445$ & $2,851,594$ & \\
\hline \multirow[t]{2}{*}{ Classification COG } & $499,559(17.07 \%)$ & $622,533(21.83 \%)$ & \\
\hline & Control & $\mathrm{MbCD}$ & Total \\
\hline Different categories identifiable (COG) & 3,625 & 4,160 & 4,415 \\
\hline Statistically different functions & n.a. & n.a. & $1,408(31.89 \%)^{1}$ \\
\hline Up-regulation with MbCD treatment & n.a. & $785(55.75 \%)^{2}$ & n.a. \\
\hline Down-regulation with $\mathrm{MbCD}$ treatment & $623(44.25 \%)^{2}$ & n.a. & n.a. \\
\hline
\end{tabular}

n.a. not applicable, ${ }^{1}$ percentage of total different categories, ${ }^{2}$ percentage of statistically different functions.

From a total of 4,415 identified transcripts, 1,408 (31.89\%) had their transcription significantly modified. Among these, 785 genes were up-regulated and 623 were down-regulated after cholesterol depletion. 
Table 2 Most abundant down-regulated functions

\begin{tabular}{|c|c|c|c|c|c|c|c|c|}
\hline COG level 2 & COG level 3 & COG function & $\begin{array}{l}\text { Control relative } \\
\text { frequency }(\%)\end{array}$ & $\begin{array}{l}\text { MbCD relative } \\
\text { frequency }(\%)\end{array}$ & $\begin{array}{l}\text { Corrected } \\
\text { p-values }\end{array}$ & $\begin{array}{l}\text { Effect } \\
\text { size }\end{array}$ & $\begin{array}{l}95.0 \% \\
\text { lower } \mathrm{Cl}\end{array}$ & $\begin{array}{c}95.0 \% \\
\text { upper } \mathrm{Cl}\end{array}$ \\
\hline Cell growth and death & Apoptosis & $\begin{array}{l}\text { Interleukin-1 receptor- } \\
\text { associated kinase } 2\end{array}$ & 0.012 & 0.000 & $5.30 \mathrm{E}-20$ & 0.012 & 0.008 & 0.015 \\
\hline Cell communication & Focal adhesion & $\begin{array}{l}\text { Platelet derived growth } \\
\text { factor } C / D\end{array}$ & 0.040 & 0.016 & $7.68 \mathrm{E}-14$ & 0.024 & 0.018 & 0.031 \\
\hline $\begin{array}{l}\text { Transport and } \\
\text { catabolism }\end{array}$ & Phagosome & $\begin{array}{c}\text { Rab-interacting lysosomal } \\
\text { protein }\end{array}$ & 0.008 & 0.000 & $1.73 \mathrm{E}-13$ & 0.008 & 0.005 & 0.011 \\
\hline Cell communication & Tight junction & GTPase KRas & 0.008 & 0.000 & $1.73 \mathrm{E}-13$ & 0.008 & 0.005 & 0.011 \\
\hline Cell growth and death & Cell cycle & $\begin{array}{l}\text { Growth arrest and DNA } \\
\text { damage-inducible protein }\end{array}$ & 0.062 & 0.035 & $2.54 \mathrm{E}-09$ & 0.027 & 0.018 & 0.035 \\
\hline Cell growth and death & Cell cycle & Regulator of sigma E protease & 0.108 & 0.072 & $3.14 \mathrm{E}-09$ & 0.036 & 0.024 & 0.048 \\
\hline Cell growth and death & Cell cycle & $\begin{array}{c}\text { Proliferating cell nuclear } \\
\text { antigen }\end{array}$ & 0.115 & 0.080 & $4.06 \mathrm{E}-08$ & 0.035 & 0.023 & 0.047 \\
\hline $\begin{array}{l}\text { Transport and } \\
\text { catabolism }\end{array}$ & Lysosome & AP-4 complex subunit mu-1 & 0.005 & 0.000 & 8.67E-08 & 0.005 & 0.002 & 0.007 \\
\hline Cell growth and death & Meiosis & $\begin{array}{l}\text { Meiosis induction protein } \\
\text { kinase IME2/SME1 }\end{array}$ & 0.004 & 0.000 & $1.91 \mathrm{E}-07$ & 0.004 & 0.002 & 0.007 \\
\hline Cell growth and death & Cell cycle & $\begin{array}{l}\text { RAD24; cell cycle checkpoint } \\
\text { protein }\end{array}$ & 0.004 & 0.000 & 4.09E-07 & 0.004 & 0.002 & 0.006 \\
\hline Cell communication & $\begin{array}{l}\text { Adherens } \\
\text { junction }\end{array}$ & $\begin{array}{c}\text { Sorbin and } \mathrm{SH} 3 \text { domain } \\
\text { containing } 1\end{array}$ & 0.004 & 0.000 & $4.08 \mathrm{E}-07$ & 0.004 & 0.002 & 0.006 \\
\hline Cell communication & Focal adhesion & $\begin{array}{l}\text { Fast skeletal myosin } \\
\text { light chain } 2\end{array}$ & 0.420 & 0.356 & $5.04 \mathrm{E}-07$ & 0.064 & 0.041 & 0.088 \\
\hline $\begin{array}{l}\text { Transport and } \\
\text { catabolism }\end{array}$ & Lysosome & $\begin{array}{c}\text { cathepsin A } \\
\text { (carboxypeptidase C) }\end{array}$ & 0.032 & 0.016 & $5.05 \mathrm{E}-07$ & 0.016 & 0.010 & 0.022 \\
\hline Cell communication & Tight junction & Myosin heavy chain & 1.108 & 1.002 & $5.82 \mathrm{E}-07$ & 0.105 & 0.067 & 0.144 \\
\hline Cell growth and death & Cell cycle & $\begin{array}{c}\text { Cyclin-dependent kinase } \\
\text { inhibitor } 1 \mathrm{~A}\end{array}$ & 0.039 & 0.022 & $1.43 \mathrm{E}-06$ & 0.017 & 0.010 & 0.024 \\
\hline $\begin{array}{l}\text { Transport and } \\
\text { catabolism }\end{array}$ & Lysosome & Arylsulfatase B & 0.004 & 0.000 & $1.90 \mathrm{E}-06$ & 0.004 & 0.002 & 0.006 \\
\hline Cell growth and death & Cell cycle & Cyclin E & 0.003 & 0.000 & 8.83E-06 & 0.003 & 0.001 & 0.005 \\
\hline Cell communication & Focal adhesion & Actinin alpha & 0.363 & 0.309 & $9.84 \mathrm{E}-06$ & 0.053 & 0.031 & 0.075 \\
\hline Cell growth and death & Cell cycle & $\begin{array}{l}\text { Cell cycle sensor histidine } \\
\text { kinase DivJ }\end{array}$ & 0.015 & 0.006 & $1.30 \mathrm{E}-05$ & 0.009 & 0.005 & 0.013 \\
\hline Cell communication & Gap junction & Cyclin-dependent kinase 1 & 0.048 & 0.030 & $2.08 \mathrm{E}-05$ & 0.018 & 0.010 & 0.025 \\
\hline
\end{tabular}

of nuclei within MbCD treated-myotubes as compared to control was also observed (Figure 1). Quantification of myoblast fusion (the number of nuclei in myotubes divided by the total number of nuclei) in cultures grown for 48 hours (untreated and MbCD treated) showed that treatment of myogenic cells with MbCD induces a $15 \%$ increase in myoblast fusion. These results showed that MbCD enhances myogenesis by the increase in myoblast fusion which leads to the formation of thicker well-striated myotubes.

Interstingly, alpha-actinin mRNA was up-regulated in myogenic cells after MbCD treatment (Additional file 1: Table S1). These transcriptomic results are in accordance with the enhancement in the number of striated myofibrils observed in the immunolabeling for alpha-actinin in
MbCD-treated myotubes as compared to untreated cultures (Additional file 1 and Figure 1).

A schematic representation of the effects of cholesterol depletion in chick cultures of myogenic cells is shown in Figure 2. Briefly, primary cultures of chick myoblasts treated with MbCD shows an enhancement in cell proliferation and fusion leading to the formation of thicker myotubes, as compared to untreated cultures. Nuclei appear clustered in the central region of $\mathrm{MbCD}$-treated myotubes, while in untreated cultures the nuclei are well aligned at the periphery of myotubes (Figure 2, nuclei in blue). Cholesterol depletion induces the formation of large areas of membrane adhesion in adjacent myoblast prior to cell fusion (Figure 2, red lines). In both control and MbCD-treated cultures it is possible to see the 
Table 3 Most abundant up-regulated functions

\begin{tabular}{|c|c|c|c|c|c|c|c|c|}
\hline COG level 2 & COG level 3 & COG function & $\begin{array}{l}\text { Control relative } \\
\text { frequency (\%) }\end{array}$ & $\begin{array}{l}\mathrm{MbCD} \text { relative } \\
\text { frequency (\%) }\end{array}$ & $\begin{array}{c}\text { Corrected } \\
\text { p-values }\end{array}$ & $\begin{array}{c}\text { Effect } \\
\text { size }\end{array}$ & $\begin{array}{c}95.0 \% \\
\text { lower } \mathrm{Cl}\end{array}$ & $\begin{array}{c}95.0 \% \\
\text { upper } \mathrm{Cl} \\
\end{array}$ \\
\hline Cell communication & $\begin{array}{l}\text { Adherens } \\
\text { junction }\end{array}$ & Lim domain only protein 7 & 0 & 0.036 & $3.37 \mathrm{E}-55$ & -0.040 & -0.041 & -0.030 \\
\hline $\begin{array}{l}\text { Cell growth and } \\
\text { death }\end{array}$ & Apoptosis & $\begin{array}{l}\text { CAMP-dependent protein } \\
\text { kinase regulator }\end{array}$ & 0 & 0.028 & $4.69 \mathrm{E}-43$ & -0.028 & -0.032 & -0.023 \\
\hline $\begin{array}{l}\text { Transport and } \\
\text { catabolism }\end{array}$ & Lysosome & $\begin{array}{l}\text { Lysosomal-associated } \\
\text { membrane protein } 1 / 2\end{array}$ & 0 & 0.025 & 4.35E-39 & -0.025 & -0.030 & -0.021 \\
\hline $\begin{array}{l}\text { Cell growth and } \\
\text { death }\end{array}$ & $\begin{array}{l}\text { p53 signaling } \\
\text { pathway }\end{array}$ & Cytochrome c & 0 & 0.023 & $3.30 \mathrm{E}-36$ & -0.023 & -0.028 & -0.019 \\
\hline $\begin{array}{l}\text { Cell growth and } \\
\text { death }\end{array}$ & $\begin{array}{l}\text { p53 signaling } \\
\text { pathway }\end{array}$ & $\begin{array}{l}\text { BH3 interacting domain } \\
\text { death agonist }\end{array}$ & 0 & 0.021 & $1.01 \mathrm{E}-32$ & -0.021 & -0.025 & -0.017 \\
\hline $\begin{array}{l}\text { Transport and } \\
\text { catabolism }\end{array}$ & Lysosome & CD63 antigen & 0 & 0.021 & $1.82 \mathrm{E}-32$ & -0.021 & -0.025 & -0.017 \\
\hline $\begin{array}{l}\text { Cell growth and } \\
\text { death }\end{array}$ & Cell cycle & Regulatory protein SWI5 & 0 & 0.021 & $3.25 \mathrm{E}-32$ & -0.021 & -0.025 & -0.017 \\
\hline $\begin{array}{l}\text { Cell growth and } \\
\text { death }\end{array}$ & Oocyte meiosis & Aurora kinase A & 0 & 0.020 & $6.84 \mathrm{E}-31$ & -0.020 & -0.024 & -0.016 \\
\hline $\begin{array}{l}\text { Transport and } \\
\text { catabolism }\end{array}$ & Lysosome & $\begin{array}{l}\text { AP-3 complex subunit } \\
\text { delta-1 }\end{array}$ & 0 & 0.019 & $1.69 \mathrm{E}-29$ & -0.019 & -0.023 & -0.015 \\
\hline Cell communication & Focal adhesion & Classical protein kinase $\mathrm{C}$ & 0 & 0.019 & $9.94 \mathrm{E}-29$ & -0.019 & -0.022 & -0.015 \\
\hline $\begin{array}{l}\text { Transport and } \\
\text { catabolism }\end{array}$ & Endocytosis & $\begin{array}{l}\text { Hepatocyte growth factor- } \\
\text { regulated tyrosine kinase }\end{array}$ & 0 & 0.018 & $3.59 E-27$ & -0.018 & -0.021 & -0.014 \\
\hline $\begin{array}{l}\text { Transport and } \\
\text { catabolism }\end{array}$ & $\begin{array}{l}\text { Regulation of } \\
\text { autophagy }\end{array}$ & $\begin{array}{c}\text { Autophagy-related protein } \\
4\end{array}$ & 0 & 0.017 & $1.24 \mathrm{E}-26$ & -0.017 & -0.021 & -0.014 \\
\hline $\begin{array}{l}\text { Transport and } \\
\text { catabolism }\end{array}$ & Phagosome & $\begin{array}{l}\text { Vesicle transport protein } \\
\text { SEC22 }\end{array}$ & 0 & 0.017 & $1.58 \mathrm{E}-25$ & -0.017 & -0.020 & -0.013 \\
\hline Cell motility & $\begin{array}{c}\text { Regulation of } \\
\text { actin cytoskeleton }\end{array}$ & Bradykinin receptor B2 & 0 & 0.017 & $1.57 \mathrm{E}-25$ & -0.017 & -0.020 & -0.013 \\
\hline $\begin{array}{l}\text { Transport and } \\
\text { catabolism }\end{array}$ & Endocytosis & $\begin{array}{l}\text { Vacuolar protein sorting- } \\
\text { associated protein } 45\end{array}$ & 0 & 0.015 & 1.10E-23 & -0.015 & -0.018 & -0.012 \\
\hline $\begin{array}{l}\text { Transport and } \\
\text { catabolism }\end{array}$ & Lysosome & $\begin{array}{l}\text { AP-1 complex subunit } \\
\text { sigma } 1 / 2\end{array}$ & 0 & 0.014 & 1.47E-21 & -0.014 & -0.017 & -0.011 \\
\hline $\begin{array}{l}\text { Transport and } \\
\text { catabolism }\end{array}$ & Endocytosis & $\begin{array}{l}\text { ESCRT-I complex } \\
\text { subunit MVB12 }\end{array}$ & 0 & 0.014 & $9.84 \mathrm{E}-21$ & -0.014 & -0.017 & -0.010 \\
\hline $\begin{array}{l}\text { Cell growth and } \\
\text { death }\end{array}$ & Cell cycle & $\begin{array}{l}\text { ATP-dependent Lon } \\
\text { protease }\end{array}$ & 0 & 0.012 & $7.22 \mathrm{E}-18$ & -0.012 & -0.015 & -0.009 \\
\hline Cell communication & Focal adhesion & p21-activated kinase 1 & 0 & 0.011 & $2.45 \mathrm{E}-17$ & -0.012 & -0.011 & -0.008 \\
\hline Cell communication & $\begin{array}{l}\text { Adherens } \\
\text { junction }\end{array}$ & Snail 2 & 0 & 0.011 & $2.43 \mathrm{E}-17$ & -0.012 & -0.011 & -0.008 \\
\hline $\begin{array}{l}\text { Transport and } \\
\text { catabolism }\end{array}$ & Endocytosis & $\begin{array}{l}\text { E3 ubiquitin-protein } \\
\text { ligase NRDP1 }\end{array}$ & 0 & 0.011 & $3.15 \mathrm{E}-16$ & -0.011 & -0.014 & -0.008 \\
\hline Cell communication & Focal adhesion & Calpain-2 & 0 & 0.011 & $5.87 \mathrm{E}-16$ & -0.011 & -0.014 & -0.008 \\
\hline
\end{tabular}

formation of periodic striations in myobrils, but there is a higher number of myofibrils in MbCD treated-myotubes than in control myotubes.

Since the Lim domain only protein 7 (LMO7) mRNA was found to be the highest up-regulated feature, we decided to investigate the distribution of LMO7 protein in chick myogenic cells. Immunofluorescence labeling of untreated muscle cell cultures with a polyclonal antibody against LMO7 revealed a strong perinuclear distribution in multinucleated myotubes, plus diffuse cytoplasmic fibrillar localization in both mononucleated and multinucleated cells (Figure 3). No differences were observed in LMO7 distribution in chick myogenic cells after MbCD treatment.

\section{Discussion}

The transcriptomic analysis presented in this study constitutes the first characterization of the genes involved in the response of muscle cells to membrane cholesterol depletion. Our results suggest that the cholesterol depleting 

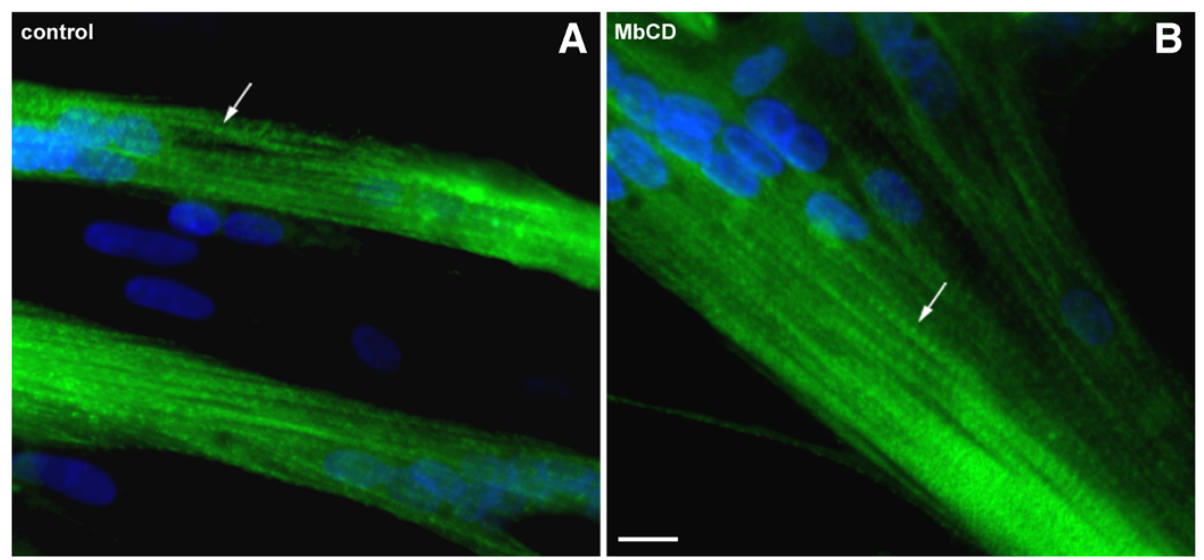

Figure 1 Methyl- $\beta$-cyclodextrin enhances muscle differentiation. Chick myogenic cells were grown for 24 hours, treated with $2 \mathrm{mM}$ of methyl- $\beta$-cyclodextrin (MbCD) for 30 minutes and grown for the next 24 hours. Untreated (A) and MbCD-treated cells (B) were fixed and doublestained with an anti-sarcomeric a-actinin antibody (green) and the nuclear dye DAPI (blue). Merged images are shown in $\mathbf{A}$ and $\mathbf{B}$. Note the a-actinin distribution in Z-lines along sarcomeres in both untreated and MbCD-treated muscle cells (arrows in $\mathbf{A}$ and $\mathbf{B}$ ). Scale bar in $\mathbf{B}$ represents $10 \mu \mathrm{m}$.

drug methyl- $\beta$-cyclodextrin induces major changes in the expression of several genes related to apoptosis, focal adhesion, phagosome, tight junction, cell cycle, lysosome, adherens junctions, gap junctions, p53 signaling pathway, endocytosis, regulation of autophagy and regulation of actin cytoskeleton. Some of the induced genes observed in this study code for well-characterized proteins. For instance, Lim domain only protein 7 (LMO7), lysosomalassociated membrane protein $1 / 2$ (LAMP $1 / 2$ ), hepatocyte growth factor-regulated tyrosine kinase substrate and calpain 2 were all up-regulated in muscle cells after cholesterol depletion.

LMO7 mRNA, which was found to be the highest upregulated feature, is an emerin-binding protein that regulates the transcription of muscle-specific genes [11]. It has been shown that LMO7 localizes in the nucleus, cytoplasm and cell surface, particularly in cadherin basedadhesion junctions and focal adhesions [12]. Holaska and colleagues speculated that specific signals might release LMO7 from the cell surface, favoring its nuclear localization and enhancing the expression of emerin and other LMO7-dependent genes involved in muscle differentiation. In the present study, we found LMO7 in a perinuclear distribution in multinucleated myotubes, and with diffuse cytoplasmic fibrillar localization in both mononucleated and multinucleated cells. Our group is currently investigating the role of LMO7 during MbCDinduced muscle differentiation. Interestingly, other adhesion proteins, besides LMO7, were found to have their transcription regulated by cholesterol depletion. Adhesion

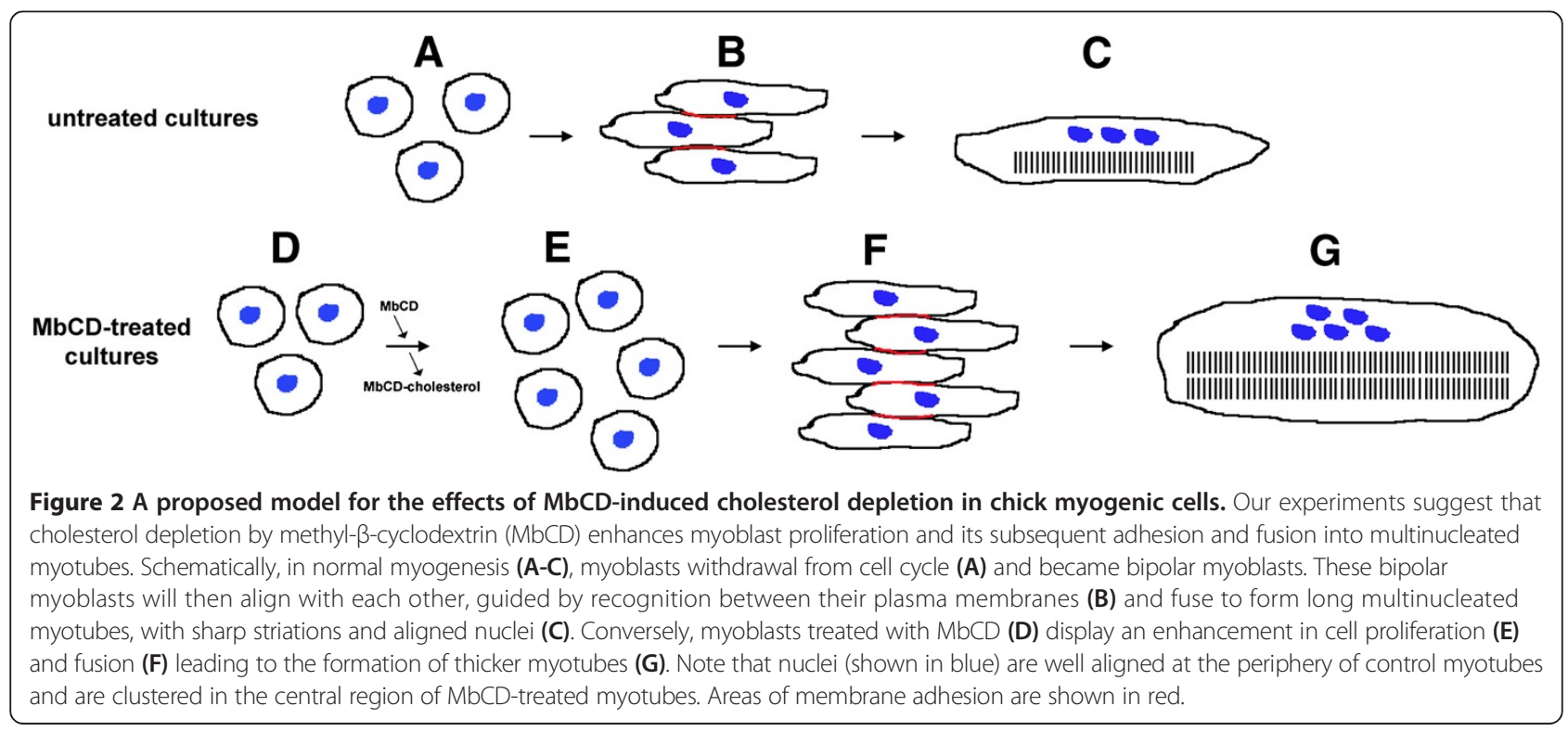



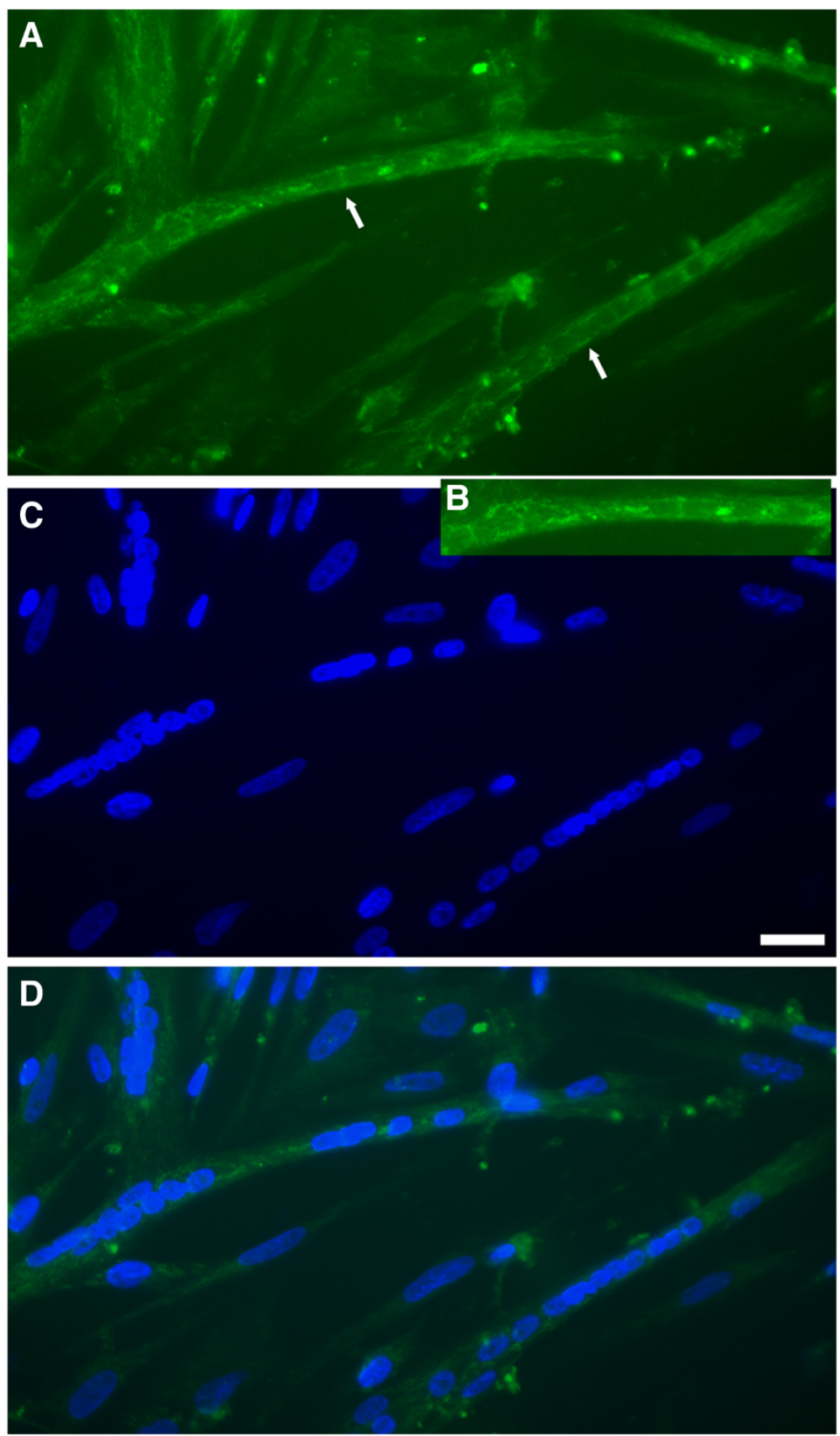

Figure 3 Lim domain only protein 7 (LMO7) localizes at the nuclei region of chick myotubes. Chick myogenic cells were grown for 48 hours and double-stained with an anti-LMO7 antibody (green, A, B, D) and the nuclear dye DAPI (blue, C, D). B is an inset of a region of image A. A merged image is shown in $\mathbf{D}$. Note the strong nuclear envelope staining of the anti-LMO7 antibody in multinucleated myotubes (arrows in $\mathbf{A}$ ), plus a diffuse cytoplasmic fibrillar staining in both mononucleated and multinucleated cells. Scale bar in C represents $20 \mu \mathrm{m}$.

proteins related to adherens junctions, tight junctions, gap junctions and focal adhesion belong to the group of transcripts altered after MbCD treatment (see Tables 2 and 3). Myoblast migration and its subsequent fusion into multinucleated cells are two processes that are highly dependent on cell-cell and cell-extracellular matrix adhesion proteins, and since MbCD enhances myoblast fusion [7], we can hypothesize that the adhesion-related transcripts that were regulated after $\mathrm{MbCD}$ are involved in the enhancement of myoblast fusion.

Calpain 2 is one of the adhesion-related mRNA that was up-regulated after cholesterol depletion. Calpain 2, also called m-calpain, is a cytosolic protease, which has been shown to be involved in the membrane reorganization 
that precedes myoblast fusion [13,14]. Further, Goudenege and colleagues [15] demonstrated the presence of active $\mathrm{m}$-calpain in myotube caveolae. The increase in the expression of $\mathrm{m}$-calpain after $\mathrm{MbCD}$ treatment is in agreement with our previous work showing that cholesterol depletion induces an increase in myoblast fusion [7].

mRNAs that are involved in the regulation of membrane traffic were also altered after cholesterol depletion, as we can observe by the changes in the expression of transcripts related to endocytosis, lysosomes and phagosomes (see Tables 2 and 3). Another was the lysosomalassociated membrane protein 1/2 (LAMP 1/2). LAMP-1 and LAMP-2 are the most abundant glycoproteins of lysosomal membranes, and its mRNAs were found in our study to be highly up-regulated after cholesterol depletion. In embryonic fibroblasts, mutual disruption of both LAMPs is associated with an increased accumulation of autophagic vacuoles, altered lysosomal appearance, and disturbed cholesterol metabolism. It has been shown that unesterified cholesterol accumulates in endo/lysosomal compartments in LAMP double deficient cells [16]. These results suggest a clear connection between the expression and localization of LAMP proteins and cholesterol. The precise role of LAMP proteins during MbCD-induced muscle differentiation needs to be further investigated.

Another transcript involved in the regulation of membrane traffic and which transcription was found altered after $\mathrm{MbCD}$ treatment was the hepatocyte growth factorregulated tyrosine kinase substrate (HGS, HRS, VPS27). It has been reported that galactosylceramide expression factor-1 (GEF-1), a rat homolog of hepatocyte growth factor regulated tyrosine kinase substrate, induces myogenesis in MDCK and C3H10T1/2 cells [17]. Since previous data from our group shows that cholesterol depletion enhances skeletal muscle myogenesis [7-10], we can suggest that HGS is involved in the induction of myogenesis observed in chick myogenic cells after exposure to MbCD.

Interestingly, many cell cycle-related mRNAs were found to have their transcription altered (either up- or down-regulated) after cholesterol depletion. A previous work from our group has shown that cholesterol depletion by $\mathrm{MbCD}$ interferes with myoblast proliferation by enhancing the proliferation of chick myogenic cells grown in culture [10]. We found an increase in the levels of p53 expression in $\mathrm{MbCD}$ treated-cells when compared to untreated cells [10]. In the present transcriptomic analysis we found the following regulators of cell cycle and p53 signaling pathway altered after $\mathrm{MbCD}$ treatment: regulatory protein SWI5, ATP-dependent Lon protease, growth arrest and DNA-damage-inducible protein, regulator of sigma E protease, proliferating cell nuclear antigen, cell cycle checkpoint protein RAD24, cyclin dependent kinase inhibitor 1A, cyclin E, cytochrome $\mathrm{c}$ and $\mathrm{BH} 3$ interacting domain death agonist.
Importantly, our results show that from a total of 4,415 identified transcripts, 1,408 (31.89\%) had their transcription significantly modified in myogenic cells after $\mathrm{MbCD}$ treatment. $\mathrm{MbCD}$ is widely used as raft-disorganizing agent, since it can remove cholesterol from cell membranes and rafts are highly enriched and dependent on cholesterol. These experiments assume that the major effect of MbCD is the removal of membrane cholesterol. Our work describes a high number of transcripts that have altered (either up- or down-regulated) expression, and therefore care should be taken when using $\mathrm{MbCD}$ as a raft-disrupting agent without looking at other possible MbCD-related effects.

\section{Conclusions}

This study analyzed the transcriptome of chick cultured muscle cells after cholesterol depletion. Our data shows that alterations in the availability of plasma membrane cholesterol lead to transcriptional changes in myogenic cells. These results could contribute to the understanding of the role of membrane cholesterol during normal skeletal muscle differentiation, as well as in pathological muscular degenerative disorders.

\section{Methods}

\section{Antibodies and probes}

DNA-binding probe DAPI (4,6-Diamino-2-phenylindole dyhydrochloride) was purchased from Molecular Probes (USA). Rabbit polyclonal anti-desmin antibody, mouse monoclonal anti-sarcomeric $\alpha$-actinin antibody (clone EA53) and rabbit polyclonal anti-LMO7 antibody were from Sigma-Aldrich (USA). Alexa Fluor 488-goat antimouse/rabbit IgG antibodies were from Molecular Probes (USA).

\section{Primary myogenic cell cultures}

This study using chick embryos was approved by the Ethics Committee for Animal Care and Use in Scientific Research from the Federal University of Rio de Janeiro and received the approval number: DAHEICB 004. All cell culture reagents were purchased from Invitrogen (São Paulo, Brazil). Primary cultures of myogenic cells were prepared from breast muscles of 11-day-old chick embryos [7]. Chick embryos were obtained from Granja Tolomei (Rio de Janeiro, Brazil). Cells were plated at an initial density of $2.5 \times 10^{4}$ cells $/ 35 \mathrm{~mm}$ culture dishes onto $22 \mathrm{~mm}$-aclar plastic coverslips (Pro-Plastics Inc., USA) previously coated with rat tail collagen. Cells were grown in $2 \mathrm{ml}$ of medium (Minimum Essential Medium with the addition of $10 \%$ horse serum, $0.5 \%$ chick embryo extract, $1 \%$ L-glutamine and $1 \%$ penicillinstreptomycin) under humidified $5 \% \mathrm{CO}_{2}$ atmosphere at $37^{\circ} \mathrm{C}$. 24-h cultures were treated for 30 minutes with methyl- $\beta$-cyclodextrin (MbCD; Sigma-Aldrich) at a final 
concentration of $2 \mathrm{mM}$. The $2 \mathrm{mM}$ final concentration of $\mathrm{MbCD}$ was chosen for cell culture treatments because our group has previously shown that $2 \mathrm{mM}$ of MbCD is sufficient to induce skeletal and cardiac muscle cell differentiation without interfering with cell viability [7-10,18]. After treatment, cultures were washed with fresh cultured medium and grown for the next 24 hours.

The percentage of myoblasts in these chick myogenic cell cultures was calculated by the double-labeling of 24 hour cultures with both DAPI (nuclear staining) and anti-desmin antibody (as a muscle-specific marker) and subsequently counting the number of desmin-positive mononucleated cells out of the total number of cells in the field. On average, myoblasts made up $80 \%$ of each culture and non-myogenic cells comprised $20 \%$.

\section{Immunofluorescence and digital image acquisition}

Cells were rinsed with Phosphate Buffered Saline (PBS) and fixed with $4 \%$ paraformaldehyde in PBS for $10 \mathrm{~min}$ at room temperature. They were then permeabilized with $0.5 \%$ Triton-X 100 in PBS 3 times for $10 \mathrm{~min}$. The same solution was used for all subsequent washing steps. Cells were incubated with primary antibodies for $1 \mathrm{~h}$ at $37^{\circ} \mathrm{C}$. After incubation, cells were washed for $30 \mathrm{~min}$ and incubated with Alexa Fluor-conjugated secondary antibodies for $1 \mathrm{~h}$ at $37^{\circ} \mathrm{C}$, and nuclei were labeled with DAPI $(0.1 \mu \mathrm{g} / \mathrm{ml}$ in $0.9 \% \mathrm{NaCl})$. Cells were mounted in Prolong gold (Molecular Probes, USA) and examined with an Axiovert 100 microscope (Carl Zeiss, Germany). Image processing was performed using Fiji software (based on ImageJ, http://imageJ.nih.gov/ij/). Control experiments with no primary antibodies showed only a faint background staining (data not shown).

\section{Quantification of fusion index and myofibrils number}

Cultures (untreated and MbCD treated) were fixed and labeled with an anti-sarcomeric alpha-actinin antibody and the nuclear dye DAPI. Nuclei (from mononucleated and multinucleated cells) were counted in fifty randomly chosen microscope fields (3 culture dishes, 50 fields in each dish) at a magnification of $\mathrm{x} 400$. The fusion index is defined as the number of nuclei in myotubes divided by the total number of nuclei. A myotube was defined by the presence of at least three nuclei within a continuous cell membrane. The number of myofibrils present within myotubes was counted in fifty randomly chosen microscope fields (3 culture dishes, 50 fields in each dish) at a magnification of $\mathrm{x} 400$.

\section{Ion Torrent-based cDNA sequencing}

The messenger RNA from chick skeletal muscle cells was extracted and isolated by Dynabeads mRNA DIRECT Micro Kit (Invitrogen). Samples were pooled from three biological replicates each. The library preparation was carried out using the Ion Total RNA-Seq Kit v2 (Life Technologies) with 500 ng of PolyA (RNA) according to manufacturer's instructions. To assess the yield and size distribution of the fragmented RNA we used Qubit RNA Assay Kit (Invitrogen) and Agilent RNA 6000 Pico Kit (Agilent, GE). The complementary DNA (cDNA) was amplified without barcoding. The dsDNA HS Assay Kit (Invitrogen) and Agilent High Sensitivity DNA Kit (Agilent, GE) were used to assess the yield and size distribution of the amplified DNA. The template was made in One Touch System by Ion One Touch 200 template kit V2 (Life technologies) according to manufacturer's instructions. The transcriptome sequencing was performed using Ion PGM 200 Sequencing Kit (Life Technologies) with 318 chips in Ion Torrent PGM machine.

\section{Transcriptome analysis}

Q20 sequences retrieved from the Ion Browser were submitted to the online server MG-Rast [19] with default Quality Control configuration and to http://www.ensembl. org/Gallus_gallus/Info/Index. QC-passed reads were functionally annotated using the COG database, with minimum e-value of $10^{-5}$, minimum identity of $60 \%$ and minimum alignment length of 15 .

\section{Availability of supporting data}

The data sets supporting the results of this article are available in the MG-Rast website repository, through the IDs 4512803.3 (Transcriptome control) and 4512804.3 (MCD-treated). Hyperlink to datasets in: http://metage nomics.anl.gov/linkin.cgi?metagenome $=4512803.3 \mathrm{http}: / /$ metagenomics.anl.gov/linkin.cgi? metagenome=4512804.3.

\section{Statistical analysis}

Metagenomic data requires particular statistical analyses, given the nature of the data. The statistical analysis performed was based on the difference between confidence intervals for each category, in each group (control and MbCD treated cells), with proper multiple test correction. Up-regulated transcripts were defined by more abundant expression in treatment than control, while downregulation was defined by more abundant expression in control than treatment.

Statistical comparison was performed on the freely available Statistical Analysis of Metagenomic Profiles (STAMP) software - version 2.0 [20]. The analysis involved a two-sided hybrid G-test with Yates correction plus an applied Fisher's exact test; 0.95 confidence intervals were calculated by asymptotic approach with continuity correction and multiple test correction involved Storey's False Discovery Rate method. P-values less than 0.05 indicated statistical differences. 


\section{Additional file}

Additional file 1: Complete transcriptomic analysis of total mRNA expressed in chick cultured muscle cells after cholesterol depletion. Over 8.5 million sequences were obtained, from which over 5.7 million passed quality control, representing 671.38 mega basepairs of information.

\section{Competing interests}

The authors declare that they have no competing interests.

\section{Authors' contributions}

ACBP carried out the cell cultures and the immunofluorescence experiments. MM carried out the lon Torrent-based CDNA sequencing. GBG performed the statistical analysis. GBG, FLT, MLC and CM participated in the analysis and interpretation of the data. CM wrote the manuscript. All authors read and approved the final manuscript.

\section{Acknowledgements}

We wish to thanks Juliana Lourenço for her expert technical assistance. This work was supported by Brazilian grants from the Conselho Nacional de Desenvolvimento Científico e Tecnológico (CNPq), Fundação Carlos Chagas Filho de Apoio à Pesquisa do Estado do Rio de Janeiro (FAPERJ), Fundação do Câncer/Programa de Oncobiologia (Rio de Janeiro), and Coordenação de Aperfeiçoamento de Pessoal de Nível Superior (CAPES).

\section{Author details}

${ }^{1}$ Instituto de Ciências Biomédicas, Universidade Federal do Rio de Janeiro, Rio de Janeiro, Brazil. 'Fundação Oswaldo Cruz, Rio de Janeiro, Brazil. ${ }^{3}$ Departamento de Ciências do Mar, Unifesp Baixada Santista, São Paulo, Brazil. ${ }^{4}$ Instituto de Biologia, Universidade Federal do Rio de Janeiro, Rio de Janeiro, Brazil.

Received: 7 March 2014 Accepted: 9 June 2014

Published: 30 June 2014

\section{References}

1. van der Bosch J, Schudt C, Pette D: Influence of temperature, cholesterol, dipalmitoyllecithin and $\mathrm{Ca}^{2+}$ on the rate of muscle cell fusion. Exp Cell Res 1973, 82:433-438.

2. Hirayama E, Sasao N, Yoshimasu S, Kim J: K252a, an indrocarbazole derivative, causes the membrane of myoblasts to enter a fusion-capable state. Biochem Biophys Res Commun 2001, 285:1237-1243.

3. Nakanishi $M$, Hirayama $E_{1}$ Kim J: Characterization of myogenic cell membrane: II. Dynamic changes in membrane lipids during the differentiation of mouse C2 myoblast cells. Cell Biol Int 2001, 25:971-979.

4. Sekiya T, Takenawa T, Nozawa Y: Reorganization of membrane cholesterol during membrane fusion in myogenesis in vitro: a study using the filipin-cholesterol complex. Cell Struct Funct 1984, 9:143-155.

5. Ohtani Y, Irie T, Uekama K, Fukunaga K, Pitha J: Differential effects of alpha-, beta- and gamma-cyclodextrins on human erythrocytes. Eur J Biochem 1989, 186:17-22.

6. Zidovetzki R, Levitan I: Use of cyclodextrins to manipulate plasma membrane cholesterol content: evidence, misconceptions and control strategies. Biochim Biophys Acta 2007, 1768:1311-1324.

7. Mermelstein CS, Portilho DM, Medeiros RB, Matos AR, Einicker-Lamas M, Tortelote GG, Vieyra A, Costa ML: Cholesterol depletion by methyl- $\beta$ cyclodextrin enhances myoblast fusion and induces the formation of myotubes with disorganized nuclei. Cell Tissue Res 2005, 319:289-297.

8. Mermelstein CS, Portilho DM, Mendes FA, Costa ML, Abreu JG: Wnt/betacatenin pathway activation and myogenic differentiation are induced by cholesterol depletion. Differentiation 2007, 75:184-192.

9. Portilho DM, Martins ER, Costa ML, Mermelstein CS: A soluble and active form of Wnt-3a protein is involved in myogenic differentiation after cholesterol depletion. FEBS Lett 2007, 581:5787-5795.

10. Portilho DM, Soares CP, Morrot A, Thiago LS, Butler-Browne G, Savino W Costa ML, Mermelstein C: Cholesterol depletion by methyl- $\beta$-cyclodextrin enhances cell proliferation and increases the number of desmin-positive cells in myoblast cultures. Eur J Pharmacol 2012, 694:1-12.
11. Holaska JM, Rais-Bahrami S, Wilson KL: Lmo7 is an emerin-binding protein that regulates the transcription of emerin and many other musclerelevant genes. Hum Mol Genet 2006, 15:3459-3472.

12. Ooshio T, Irie K, Morimoto K, Fukuhara A, Imai T, Takai Y: Involvement of LMO7 in the association of two cell-cell adhesion molecules, nectin and E-cadherin, through afadin and alpha-actinin in epithelial cells. J Biol Chem 2004, 279:31365-31373.

13. Dourdin N, Brustis JJ, Balcerzak D, Elamrani N, Poussard S, Cottin P Ducastaing A: Myoblast fusion requires fibronectin degradation by exteriorized m-calpain. Exp Cell Res 1997, 235:385-394.

14. Kwak KB, Chung SS, Kim OM, Kang MS, Ha DB, Chung CH: Increase in the level of $\mathrm{m}$-calpain correlates with the elevated cleavage of filamin during myogenic differentiation of embryonic muscle cells. Biochim Biophys Acta 1993, 1175:243-249

15. Goudenege S, Poussard S, Dulong S, Cottin P: Biologically active milli-calpain associated with caveolae is involved in a spatially compartmentalised signalling involving protein kinase $C$ alpha and myristoylated alanine-rich C-kinase substrate (MARCKS). Int J Biochem Cell Biol 2005, 37:1900-1910.

16. Eskelinen EL, Schmidt CK, Neu S, Willenborg M, Fuertes G, Salvador N, Tanaka Y, Lüllmann-Rauch R, Hartmann D, Heeren J, Von Figura K, Knecht E, Saftig P: Disturbed cholesterol traffic but normal proteolytic function in LAMP-1/LAMP-2 double-deficient fibroblasts. Mol Biol Cell 2004, 15:3132-3145.

17. Ogura K, Niino YS, Tai T: Galactosylceramide expression factor-1 induces myogenesis in MDCK and C3H10T1/2 cells. Arch Biochem Biophys 2004, 426:279-285.

18. Pontes Soares C, Portilho DM, Da Silva SL, Einicker-Lamas M, Morales MM, Costa ML, Dos Santos MC: Membrane cholesterol depletion by methylbeta-cyclodextrin enhances the expression of cardiac differentiation markers. Cells Tissues Organs 2010, 192:187-199.

19. Meyer F, Paarmann D, D'Souza M, Olson R, Glass EM, Kubal M, Paczian T, Rodriguez A, Stevens R, Wilke A, Wilkening J, Edwards RA: The metagenomics RAST server - a public resource for the automatic phylogenetic and functional analysis of metagenomes. BMC Bioinformatics 2008, 9:386.

20. Parks DH, Beiko RG: Identifying biologically relevant differences between metagenomic communities. Bioinformatics 2010, 26:715-721.

doi:10.1186/1471-2164-15-544

Cite this article as: Possidonio et al:: Cholesterol depletion induces transcriptional changes during skeletal muscle differentiation. BMC Genomics 2014 15:544.

\section{Submit your next manuscript to BioMed Central and take full advantage of:}

- Convenient online submission

- Thorough peer review

- No space constraints or color figure charges

- Immediate publication on acceptance

- Inclusion in PubMed, CAS, Scopus and Google Scholar

- Research which is freely available for redistribution 